\title{
pro.posições
}

$e$-ISSN 1980-6248

http://dx.doi.org/10.1590/1980-6248-2016-0095

DOSSIÊ: Empreendimentos sociais, elite eclesiástica e congregações religiosas no Brasil República: a arte de "formar bons cidadãos e bons cristãos"

\section{Associações católicas como instâncias socializadoras e de controle do tempo: o caso do Liceu e do Santuário Sagrado Coração de Jesus ${ }^{1}$}

\section{Catholic associations as instances of socialization and time control}

(i) Universidade do Estado do Rio de Janeiro, Rio de Janeiro, RJ, Brasil. leonardi.paula@gmail.com

Resumo: Este artigo examina os interesses envolvidos na instalação do Santuário e do Liceu do Sagrado Coração de Jesus em São Paulo, apresentando as posições da elite local, do bispado e da congregação salesiana. Intenta compreender como esses edifícios e as práticas realizadas em ambos proporcionaram a difusão de uma cultura católica e a socialização dos indivíduos. Focaliza as associações como práticas que uniam padres, professores, alunos e paroquianos; que socializavam e estabeleciam uma forma de compreender o tempo e de controlá-lo. A pesquisa apoiou-se em documentação encontrada nos arquivos salesianos e da Cúria Metropolitana, ambos de São Paulo. As fontes indicam que Santuário e Liceu marcaram a paisagem da cidade em processo de urbanização, e os religiosos disputavam o interesse da população com outras atividades.

Palavras-chave: santuário, liceu, associações, salesianos

\footnotetext{
${ }^{1}$ Esta investigação compõe o Projeto Temático "Congregações católicas, educação e estado nacional no Brasil”, com financiamento Fapesp.
} 


\section{pro.posições}

$e$-ISSN 1980-6248

http://dx.doi.org/10.1590/1980-6248-2016-0095

Abstract: This article examines the interests involved in the installation of the Sanctuary and of the Lyceum of the Sacred Heart of Jesus in São Paulo, it also presents and discusses the positions of the local elite, of the bishopric and of the Salesian congregation, and aims at understanding how these institutions and practices allowed for the spread of a Catholic culture and for the socialization of individuals. The article focuses on the associations as practices that united priests, teachers, students and parishioners, who socialized and intended to establish a way of comprehending and controlling the time. The research was based on documents found in the Salesians and the Metropolitan Curia archives, both in São Paulo. The results indicate that the Sanctuary and the Lyceum marked the city landscape during the urbanization process, and that the priests disputed the interest of the population with other activities.

Keywords: sanctuary, lyceum, associations, Salesians

Esta investigação iniciou-se com o objetivo de compreender os interesses envolvidos na instalação do Liceu e do Santuário do Sagrado Coração de Jesus, em São Paulo, pela Pia Sociedade de São Francisco de Sales, e seu papel na difusão de uma cultura católica; e também de identificar práticas que transitavam por esses dois edifícios. Ao focalizar as justificativas presentes nos discursos para a construção de ambos, foi possível observar a instauração de uma prática entre eles, com a finalidade de difundir a cultura ${ }^{2}$ católica: as associações. A que serviam essas associações e quem delas participava são algumas questões que se procuram responder. Para isso, foram utilizadas fontes diversas. O Livro Tombo do Santuário, paróquia do Sagrado Coração de Jesus, e a Memória da congregação apresentam apenas informações superficiais sobre o assunto. Outras fontes, como o Annuario da Arquidiocese, uma ata de associação, programas de celebrações do Santuário e fotos auxiliaram na construção de hipóteses e na análise.

Atualmente, um passeio pelo Largo Coração de Jesus, no bairro de Campos Elíseos, região central de São Paulo, apresenta um cenário inusitado. Em meio a casarões remanescentes do século XIX, a poucas quadras do antigo Palácio de Campos Elíseos, sede do governo do estado de São Paulo entre 1912 e 1964³ , os imponentes prédios do Santuário e do Liceu do Sagrado Coração de Jesus dividem espaço com a "cracolândia". Seguem preservados na paisagem, ao contrário de outros edifícios deteriorados na região. Pelas ruas do bairro, atraem a

\footnotetext{
${ }^{2}$ Entendida, aqui, como padrões de comportamento, crenças, costumes.

${ }^{3} \mathrm{O}$ palacete foi projetado como residência de Elias Antonio Pacheco e Chaves em 1896 pelo arquiteto alemão Matheus Haüssler. Atualmente abriga a Secretaria da Ciência, Tecnologia, Desenvolvimento Econômico e Turismo do Estado de São Paulo. Retirado em 14 de junho de 2016, às 15h26, de http://www.cultura.sp.gov.br/portal/site/SEC/menuitem.bb3205c597b9e36c3664eb10e2308ca0/?vgnextoid=9 1b6ffbae7ac1210VgnVCM1000002e03c80aRCRD\&Id=becda077515bc010VgnVCM2000000301a8c0.
} 


\section{pro.posıções}

$e$-ISSN 1980-6248

http://dx.doi.org/10.1590/1980-6248-2016-0095

curiosidade da população crianças e jovens com roupas que se assemelham a trajes medievais, cobrindo boa parte de seus corpos em tons de bege e marrom. São os Arautos do Evangelho, associação que utiliza os espaços do Liceu e do Santuário ${ }^{4}$ e tem entre seus membros alguns alunos do Liceu. A despeito da deterioração do bairro, uma cultura católica mantém-se expressa nos prédios, na circulação de pessoas e nos padrões de comportamento. Não se veem mais as batinas dos padres, mas os Arautos logram atrair a atenção.

A construção dos dois prédios iniciou-se em 1881, envolvendo diferentes interesses e em meio a importantes mudanças do período. A segunda metade do século XIX e o início do século XX viram modificações nas relações de trabalho, com a imigração e com a passagem do trabalho escravo para o livre e assalariado. Aliados a esse movimento, cresciam setores de prestação de serviços e da pequena indústria, associados ao início da urbanização e ao aparecimento de um proletariado urbano, formado, sobretudo, por imigrantes. Circulava por aqui capital estrangeiro, com ingleses e, mais tarde, norte-americanos. Circulavam, também, novas tendências de pensamento, como o positivismo e o industrialismo cosmopolita (Hilsdorf, 2006). O final do século XIX foi também o da mudança de regime, com a proclamação da República (1889). Socializar a população que viveria nas cidades, o proletariado urbano, os imigrantes e os negros, mas também seus próprios filhos, fornecer-lhes padrões de conduta e formas de compreender o mundo era uma tarefa que a elite assumia como sendo sua.

Para a Igreja Católica, o Brasil era um dos territórios de missão e refúgio ${ }^{5}$, haja vista a imigração de congregações religiosas ocorrida por um período de quase 80 anos para este país (Bittencourt, 2015). A despeito da separação dos poderes e da declaração do Estado laico com a proclamação da República, a descentralização política inscrita na Constituição de 1891 oportunizou alianças locais para a instalação e o trabalho de religiosos e religiosas imigrantes (Custódio, 2014; Dallabrida, 2001; Leonardi, 2010; Neris \& Seidl, 2015). Tal como recomendavam Leão XIII e os decretos resultantes do I Concílio Plenário da América Latina

\footnotetext{
${ }^{4}$ Em sua página na Internet, o grupo afirma que se trata de uma associação internacional de fiéis, de Direito Pontifício, composta principalmente por jovens e que está presente em 78 países: "Seus membros de vida consagrada praticam o celibato, e dedicam-se integralmente ao apostolado, vivendo em casas destinadas especificamente para rapazes ou para moças, os quais alternam a vida de recolhimento, estudo e oração com atividades de evangelização nas dioceses e paróquias, dando especial ênfase à formação da juventude". Retirado em 22 de janeiro de 2016, às 17h40, de http://www.arautos.org/view/show/341-arautos-do-evangelho.

${ }^{5}$ A Igreja perdeu territórios com a unificação italiana e, também, posições de destaque em diversos governos com o avanço dos liberalismos.
} 


\section{pro.posıções}

$e$-ISSN 1980-6248

http://dx.doi.org/10.1590/1980-6248-2016-0095

(1899), as congregações lançavam mão da organização de periódicos, editoras, investimentos na área da saúde, em colégios e na construção de templos nas cidades (Actas y Decretos, 1906). Chegados ao Brasil em princípios da década de 1880, os salesianos assumiram a construção dos dois prédios, com o apoio do bispo e da elite local.

Tributária dos esforços empreendidos para compreender as relações entre educação e catolicismo a partir da História da Educação, esta pesquisa procura identificar e compreender a inscrição do catolicismo e de suas práticas de socialização na cidade. Na sua primeira parte, este artigo examina as justificativas e os interesses envolvidos na instalação do Liceu e do Santuário no bairro de Campos Elíseos. Em seguida, aborda a questão das associações, na tentativa de identificar quem delas participava e de compreender suas finalidades.

\section{Almas Desorientadas No Caos Urbano}

\section{Figura 1 - Santuário do Sagrado Coração de Jesus e Liceu de Artes e Ofícios ao lado, em construção, n.d.}

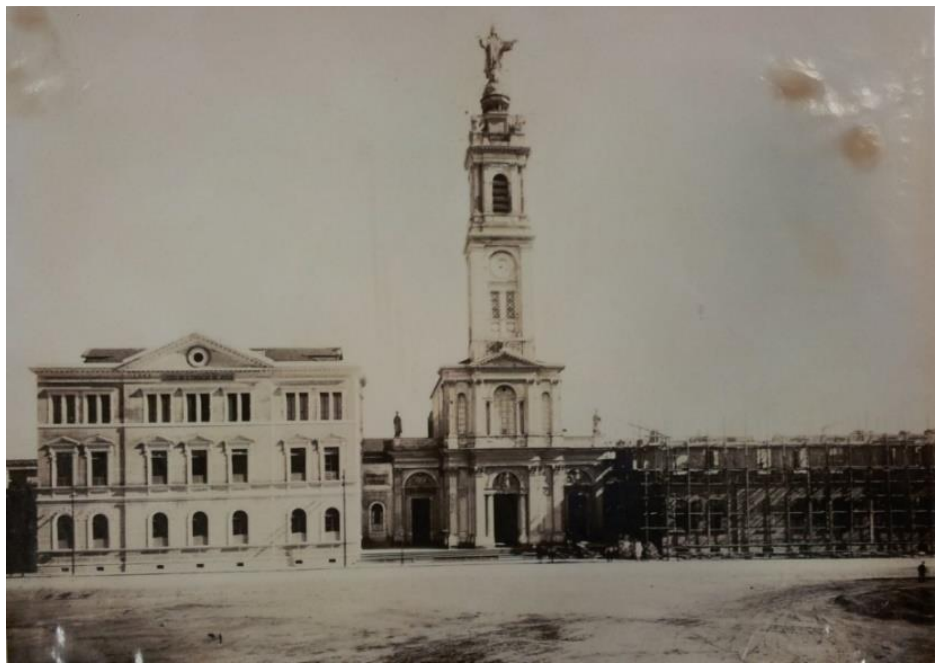

Fonte: Arquivo Salesiano de São Paulo

$\mathrm{Na}$ transição do século XIX para o século XX, as duas construções marcaram a paisagem urbana do bairro de Campos Elíseos, em um período no qual se empreendiam naquela região majestosas construções, que contribuiriam para organizar e produzir um espaço. Por ali circulariam mais e mais pessoas a cada dia. Pela grade ainda mal estruturada do Liceu seria possível observar, nos finais de semana, os padres do externato brincando de bola com os 


\section{pro.posıções}

$e$-ISSN 1980-6248

http://dx.doi.org/10.1590/1980-6248-2016-0095

garotos do Oratório Festivo, organizado para entreter com orações, jogos e música meninos pobres ou de setores médios em "perigo moral" (Isaú, 1985).

Desde a Colônia, os religiosos que aportaram no Brasil empenharam-se na construção de seus colégios ao lado das igrejas. Mudanças na organização de trabalho dos jesuítas, nos colégios e nas escolas transformaram a igreja e outras dependências, mesmo que essenciais para a prática evangelizadora, em apêndices dos colégios. Esta inversão ficou marcada no modo corrente de falar: "a igreja do colégio x" (Alves, 2005).

Um santuário, entretanto, não é apenas uma igreja. Ele é definido pela atribuição de características distintivas a um espaço por grupos sociais ou por uma instituição (Menezes, 2009). Para esse local afluem peregrinos e romeiros e, como lugares sagrados que caracterizam e diferenciam, não são apenas um aspecto da paisagem, mas também, tanto quanto as escolas, a produzem (Rosendahl, 1996), à medida que são ocupados e vivenciados pelos sujeitos de formas múltiplas. Entretanto, as maneiras de empregar o que se consome nesses espaços são impostas por uma ordem (Certeau, 1990). É isso o que se quer observar, já que não se dispõe de fontes para analisar quais usos se faziam do que se consumia nesses espaços.

Não é fácil precisar de que forma o título de santuário era outorgado naquele momento ${ }^{6}$. Uma gruta, um morro, uma estátua ou um edifício podem ser definidos como um espaço sagrado, local onde a divindade se manifesta. A definição de um local ou de um espaço como sagrado pode se dar pelas manifestações populares ou por estímulo/determinação da Igreja. De qualquer forma, mesmo que comece "espontaneamente", sem intervenção da hierarquia, a Igreja acaba por encampar esses espaços e por conferir a eles uma organização. No caso em questão nesta pesquisa, o primeiro edifício nasceu como Santuário. Quem se ocuparia dele?

No assunto da vinda e da instalação dos religiosos da Pia Sociedade de São Francisco de Sales para São Paulo estavam envolvidos os próprios salesianos, o bispo de São Paulo, Dom Lino Deodato (1873-1894), e a elite local. O primeiro edifício a ser construído foi o Santuário. A devoção ao Sagrado Coração de Jesus era estimulada pela Igreja, e sua difusão indica que provavelmente foi um dos veículos de um esforço de universalização cultural (Monteiro, 2011)

${ }^{6}$ Pelo Direito Canônico, é definido como lugar sagrado para onde aflui grande número de peregrinos. O primeiro Código data de 1917. Nele se estabelece que os santuários possam ser diocesanos (com a aprovação do bispo), nacionais (com a aprovação da Conferência Episcopal) ou internacionais (com a aprovação da Santa Sé). Retirado em 14 de maio de 2015, às 12h30, de http://paroquiavirtualfreiivo.blogspot.com.br/2010/08/diferenca-entreparoquia-e-santuario.html. 


\section{pro.posıções}

$e$-ISSN 1980-6248

empreendido pelas missões modernas. Pio IX estendeu a festa do Sagrado Coração ao calendário universal da Igreja e, depois, Leão XIII consagrou o Concílio Plenário da América Latina (1899) a essa devoção ${ }^{7}$. As cartas pastorais de D. Lino e todo o estímulo à construção do Santuário, desde o lançamento da pedra fundamental, em 24 de junho de 1881, atestam seu esforço na difusão dessa devoção na cidade de São Paulo (SSCJ, 1884).

Em Carta Pastoral datada de 27 de setembro de 1884, transcrita no Livro Tombo (SSCJ, 1884), o bispo comunicava a consagração da Diocese ao Sagrado Coração de Jesus e apontava o que seria, para ele, o objetivo do Lyceu: a educação moral e religiosa ao lado da educação profissional.

Ergue-se ao seu lado [do santuário] e já em bom pé de construção o edifício destinado para o Lyceu de Commercio, Artes e Officios, caridosa e utilíssima instituição, cujo objetivo é a educação moral e religiosa consorciada ao ensino profissional da infância, principalmente pobre e desamparada. A este auspicioso acontecimento, que devia, por si só um poderoso incentivo para o acto solemne da consagração da Diocese, prendem-se rasões não menos graves e imperiosas que justificam a necessidade desse acto, como passamos a demonstrar. (SSCJ, 1884, f.9)

Em quatro longos parágrafos, D. Lino expõe as "razões graves e imperiosas", discorre sobre os ataques que sofria a Igreja e sobre as "manifestações sobrenaturais espontâneas" que vinham em sua defesa, como o Sagrado Coração de Jesus. Os tempos difíceis que atravessavam era a época mais propícia para desenvolver essa devoção.

Pela iniciativa de alguns catholicos seculares e Revs. Sacerdotes que, animados por um duplo sentimento de religião e patriotismo, tanto se esforçam no intento de proporcionarem a educação religiosa e o ensino profissional à infância, principalmente pobre e desamparada; a obtenção de donativos e sua continuação, a despeito da dificuldade dos tempos, além do mais que omittimos, são obras de piedade, zelo e devotamento que muito honram esta diocese, ao mesmo tempo que dão testemunho irrecusável da vida sobrenatural da Egreja Catholica, em cujo seio fecundíssimo geram-se, nutrem-se e fructificam tantas instituições literárias, pias e caridosas, da mais alta e transcendente utilidade religiosa e social. (SSCJ, 1884, f. 13, verso)

\footnotetext{
${ }^{7}$ A memória dos salesianos procura marcar, à época da fundação da congregação, sua ligação com a devoção. Isaú (1985) afirma que Dom Bosco também havia recebido de Leão XIII o encargo de construir um templo ao Sagrado Coração de Jesus em Roma. O mesmo historiador revela que, apesar de ser devoção antiga no interior da Igreja, atribui-se a São Francisco de Sales, fundador da Ordem da Visitação no século XVII (e patrono dos salesianos), uma abertura de caminho para sua expansão: para a Ordem recém-criada, elegeu como armas um coração cravado de espinhos. Mais tarde, Margarida Alacoque (1647-1690), religiosa dessa congregação, em Paray-la-Monial (França, Borgonha) teria tido grandes dificuldades para convencer sua superiora das visões que teve com o Sagrado Coração. Embora se afirme que a devoção se popularizou, somente 75 anos após a morte de Margarida, a devoção foi reconhecida oficialmente pela Igreja.
} 


\section{pro.posıções \\ $e$-ISSN 1980-6248}

O bispo vincula, em seu discurso, Santuário e Liceu em torno do Sagrado Coração, unindo, também, religião e patriotismo. Ter uma utilidade religiosa era, para ele, ter uma utilidade social. Esse discurso parece ecoar nos anos seguintes, como se observa no Annuario da Arquidiocese de São Paulo para os anos 1912 e 1913, no qual se articulam ideias em torno das dificuldades que as pessoas enfrentavam para viver em grandes cidades. Em "Movimento Parochial” (Annuario, 1913), lê-se:

Derramadas pelos novos e florescentes bairros da capital, longe das matrizes, sem egrejas, sem recursos prontos e eficazes, se vão adensando as classes operarias em meio pouco favorável às tradições religiosas, preparando talvez, para o dia de amanhã, fundos dissabores para a Egreja e para o Estado. É nesse meio, pacientemente trabalhado por idéas revolucionarias, onde não chega a vOz vigilante do pastor, que florescem os anarchistas, que se multiplicam as práticas supersticiosas, que se prepara a decadência da nacionalidade brasileira, como se armam os adversários do santo nome de Deus. (p. 17) ${ }^{8}$

O discurso marca fortemente a distinção entre campo e cidade, capital e interior. A cidade é o espaço no qual os cinemas, os foot-ballers e outras diversões atraem as crianças e os jovens, rivalizando com o catecismo. É preciso fazer mais para vencer essa batalha. A solução para a desagregação que afetaria, igualmente, a Igreja e o Estado seria voltar-se para a fé católica. Para o redator do Anuário, os imigrantes desorientam-se na nova terra, e essa é a marca da vida na cidade. Por isso precisam da tutela da Igreja.

Não obstante, há em todas essas boas almas, um tanto desorientadas pelas dificuldades do primeiro momento em paiz estranho, um fundo admirável de fé, incapaz de resistir aos esforços de um vigário inteligente e zeloso. Haja vista o exemplo palpável das novas parochias de Bella Vista, S. João e mesmo da Lapa, onde se crearam e vão florescendo bellos centros de piedade e vida religiosa. (Annuario, 1913, p. 17)

O que a Igreja faz a respeito? Exemplos da construção de templos são explicitados no Annuario. Informa-se que a Arquidiocese contava, então, com 49 paróquias, dentre as quais 43 estavam providas, ou seja, administradas por um padre leigo ou por uma congregação religiosa. No entanto, mesmo providas, ainda faltavam religiosos para trabalhar com grandes populações que, segundo o redator, ultrapassavam facilmente as grandes paróquias da Europa (Annuario, 1913).

${ }^{8}$ Optou-se por manter a grafia original de todas as fontes. 


\section{pro.posıções}

$e$-ISSN 1980-6248

http://dx.doi.org/10.1590/1980-6248-2016-0095

Em toda a arquidiocese havia 352 edifícios destinados ao culto (96 igrejas e 256 capelas); 63 estabelecimentos de ensino católicos (18 colégios, sendo 13 pensionatos e 5 gratuitos; 34 escolas ou externatos e 11 asilos). Dentre as escolas, 7 eram mantidas por vigários e 8 por associações católicas. Todos os demais estabelecimentos eram mantidos por congregações religiosas. As escolas noturnas para adultos também foram mencionadas, com destaque para a dos Salesianos, com 230 alunos. A Associação de Escholas Populares, "essa tão sympathica quão modesta associação, ministra nas suas escholas ensino gratuito e religioso a 180 mocinhas operarias" (Annuario, 1913, p. 21).

No "Movimento Paroquial", ainda que não se descure da educação das crianças, o redator do Annuario indica a população foco de preocupação naquele momento - os operários e os estrangeiros - e os meios privilegiados para com ela trabalhar: os colégios e o desenvolvimento da piedade. Esta última tarefa envolve uma ampla gama de atividades, desde a participação nos sacramentos (que implica frequentar a missa, ouvir os sermões, comungar, confessar, etc.) até a adesão a uma associação ou confraria. A colaboração entre Igreja e Estado seria necessária, do ponto de vista do redator.

Para a Igreja e para alguns setores da elite, as populações rurais eram vistas como aquelas marcadas pelo catolicismo luso-brasileiro, considerado atrasado, pleno de ignorância, superstição e fanatismo (Azzi, 1994). As classes populares urbanas, tal como se viu no Annuario referido, eram tidas pelos bispos como minadas pelas ideias socialistas e anarquistas. A diocese de São Paulo, com burguesia emergente e classes médias em formação, insistiu na aliança com o Estado e indicou a necessidade de investir em áreas de imigração europeia. Nos centros urbanos, tratava-se de disputar áreas de influência, seja com as ideias liberais e positivistas, seja com o protestantismo e o espiritismo. Paróquias, colégios e associações religiosas tinham papel importante para que os valores da Igreja Católica continuassem a ser assimilados. Eram as congregações imigradas, muitas vezes pelo convite de bispos e da elite local, que os constituíam e mantinham.

A Congregação de São Francisco de Sales, desde sua criação, havia empreendido esforços para a educação/evangelização tanto da juventude quanto de adultos. A história da fundação dessa congregação é perpassada pelas disputas territoriais decorrentes da unificação da Itália (com os Estados Pontifícios sendo tomados), da centralização do poder nas mãos do papado, da crescente urbanização e industrialização e da migração, que apinhava as cidades de 


\section{pro.posıções}

http://dx.doi.org/10.1590/1980-6248-2016-0095

$e$-ISSN 1980-6248

jovens pobres (Azzi, 2000; Silva, 2011). A memória da congregação comumente representa seus padres como "modernos", apontando que os salesianos procuravam vestir-se de forma a diferir o menos possível dos leigos, envolviam-se em jogos com seus alunos, promoviam apresentações teatrais e musicais, trabalhavam com crianças e jovens de camadas médias e baixas e ensinavam profissões para a indústria.

Tanto o historiador da congregação, Riolando Azzi (2000), como a pesquisadora Paula Montero (2011) indicam que Dom Bosco, seu fundador, desenvolveu a congregação, por um lado, aliando-se ao capitalismo liberal e, por outro, criticando o mundo moderno ${ }^{9}$ e oferecendolhe um modelo, também chamado de moderno, pautado nos dogmas da Igreja ${ }^{10}$. Ele tinha uma extensa rede de relações, mesmo entre os anticlericais. Também gozava de foro privilegiado com os papas Pio IX (1846-1878) e Leão XIII (1878-1903), tendo ganhado o apelido de "Garibaldi do Papa". Assim, ele transitava entre membros do capitalismo liberal e desenvolvia uma forma de ação da Igreja no mundo apoiada pelo papado. O envio de missionários para a América Latina teve papel importante na consolidação da Congregação aos olhos da Santa Sé. O continente ocupou uma posição privilegiada em sua expansão e, ao mesmo tempo, favoreceu o estabelecimento de uma posição de destaque no Vaticano (Montero, 2011).

A vinda dos salesianos para o Brasil está vinculada à Conferência Vicentina, devota do Sagrado Coração que lhe dava nome (Conferência do Sagrado Coração, fundada em 1874), e à figura do Dr. Alberto Saladino Figueira de Aguiar, seu presidente (Arroyo, 1954). Figueira de Aguiar mandou buscar na Europa uma imagem do Sagrado Coração de Jesus, em cumprimento a um voto por ele feito. Inicialmente, foi doado por Domingos Carregaza um terreno para a construção do futuro Santuário (Isaú, 1985). O bispo, Dom Lino Deodato, não aceitou o terreno por ser pequeno. Ao que parece, Carregaza teria se antecipado aos projetos de Dom Lino (Arroyo, 1954). Feita a arrecadação de dois contos de réis, em 20 de dezembro de 1879 foi comprado, no bairro de Campos Elíseos, um terreno medindo vinte braças na Alameda Glete

\footnotetext{
9 Aqui, o sentido da palavra remete à Encíclica Quanta Cura, promulgada por Pio IX em 1864, e à lista que a acompanha, o Syllabus Errorum, enumeração dos chamados "erros modernos". Dentre eles estavam: liberalismo, racionalismo, socialismo, protestantismo, espiritismo e maçonaria. Para Duffy (1998), ambas - Encíclica e lista foram a declaração de guerra de Pio IX ao seu tempo.

${ }^{10}$ Até sua oficialização pela Igreja, Dom Bosco se equilibrava entre os desígnios do papado e as exigências legais da Itália que se unificava com grupos anticlericais com força política. Desde 1848 a congregação teve de se adequar à Restauração Italiana, que havia extinguido os tribunais eclesiásticos, proibido as corporações religiosas e leigas de adquirirem propriedades ou receberem bens sem autorização do Estado e obrigara os religiosos ao serviço militar (Montero, 2011).
} 


\section{pro.posıções}

$e$-ISSN 1980-6248

http://dx.doi.org/10.1590/1980-6248-2016-0095

e vinte braças na Alameda Barão de Piracicaba (SSCJ, 1884). Como se vê na Figura 1, tratavase de um grande empreendimento.

Irmão Alberani, da Companhia de Jesus, que residia no Colégio São Luiz Gonzaga, de Itu, traçou a primeira planta do prédio (Isaú, 1985). Em cartas pastorais, o bispo de São Paulo, D. Lino, exortava os fiéis a colaborarem com a construção do Santuário. As obras avançaram rapidamente, com a ajuda da Conferência dos Vicentinos e das esmolas conseguidas. Em circular em prol da construção do Santuário aparecem os signatários: Cônego Guimarães Barroso, Saladino Figueira de Aguiar, Dr. Raphael Corrêa da Silva Sobrinho, João José Vieira Guimarães Jr., Bernardino José Dias Soares de Oliveira, Domingos Gonçalves Carregaza, Claudio Justiniano de Souza, João Batista de Alambary Palhares, João Batista de Alvarenga. Dentre os envolvidos na construção do Liceu, estavam: o Arcediago Dr. Francisco de Paula Rodrigues, Visconde de Itu; o Barão de Mossoró; o Barão de Tremembé; o Major Antonio Martiniano de Oliveira Borges; Dr. Luiz de Camargo Mello; Dr. Antonio Francisco de Aguiar e Castro, além, é claro, de seu presidente, Dr. Alberto Saladino Figueira de Aguiar (SSCJ, 1884).

Presidentes da província, membros da nobreza, ricos comerciantes, grandes fazendeiros. Essa elite era composta, sobretudo, por proprietários de fazendas de café que, por volta de 1870, transferiram suas residências para a cidade de São Paulo, com o objetivo de ali aplicar seus excedentes em empreendimentos urbanos (Campos, 2007). Da cidade controlavam o trabalho nas lavouras e a comercialização dos produtos, participavam de diferentes atividades empresariais e imobiliárias e exerciam pressão política. O Liceu parece ter sido um duplo investimento para essa elite. Distribuíram-se cotas e esperava-se reembolsar os acionistas quando o empreendimento tivesse rendimento (SSCJ, 1884). Além disso, nesse estabelecimento se daria educação em regime de internato para filhos de fazendeiros e educação profissional em externato, formando operários para a indústria nascente.

A Circular de 10 de Janeiro de 1882, expedida por membros da comissão em favor das obras do Liceu, aponta para este duplo investimento:

Nésta obra [Santuário] já está gasta a quantia superior a 17:000\#000 réis. Foi suggerida a ideia de anexar-lhe uma instituição que a tornasse mais fecunda; o pensamento de dota-la com um estabelecimento qualquer de instrucção surgio em diversos espíritos.

A importância do ensino Professional, a absoluta necessidade que temos delle, pareceram de preferência indicar a annexação de um Lycêo de Commercio, Artes e Officios. Entre o Clero e 


\section{pro.posıções}

$e$-ISSN 1980-6248

http://dx.doi.org/10.1590/1980-6248-2016-0095

os Catholicos dedicados immediatamente se apresentaram quase 50 accionistas e para levar a termo esta empresa, deseja se principalmente o apoio e protecção do Clero desta Diocese, sempre cioso das ideias generosas; por isso pedimos a V. Revma. que se torne também accionista e que no Circulo dos seus amigos consiga mais accionistas para essa empresa começada. (SSCJ, 1884, f. 4, verso)

Os salesianos pareciam ser a congregação que melhor respondia às aspirações e às ideias de modernidade da elite paulistana que endossava a construção do santuário e do liceu. $\mathrm{Na}$ mesma Circular, indicam:

Inapreciaveis resultados tem alcançado a Sociedade Salesiana não só em relação às artes e officios, como relativamente ao ensino do commercio e das industrias, fabricando nas officinas de seus estabelecimentos o papel, fundindo tippos, imprimindo obras importantes, encadernando as. A marcenaria, a sapataria, a architetura, a pintura, a música, enfim, todas as artes e officios vieram nesses estabelecimentos em companhia da litteratura e das sciencias. São estes os nossos desejos, são estas as nossas aspirações. (SSCJ, 1884, f. 5 verso)

A querela entre o bispo e Carregaza para a compra do terreno, pouco explorada nas memórias salesianas, sugere certa discordância entre as duas partes. Para Dom Lino, a difusão de uma devoção importava tanto ou mais que a construção de um Liceu, daí a necessidade de um amplo espaço. Talvez houvesse uma discordância de tempos entre as duas partes interessadas (Charle, 2011). Uma tensão entre presente, passado e futuro nas justificativas e nos discursos, tributários da forma como acompanhavam a mudança histórica e nela procuravam intervir. Para a elite, a certeza da evolução, com o desenvolvimento e o domínio das técnicas, envolvia educar seus próprios filhos para a vida e para os tempos da cidade e formar operários. Para Dom Lino e para a Arquidiocese, tratava-se do moderno ao modo salesiano, apoiado nos valores católicos, com mestres próximos aos alunos, que com eles brincavam, promoviam teatro e música - divertimentos católicos para rivalizar com outros oferecidos pela cidade -, com trajes que diferissem pouco dos leigos; que ensinavam profissões reclamadas pelo seu tempo e como se comportar no meio urbano. Aliaram-se, contudo, aos empreendedores, para difundir esse regime de historicidade híbrido e uma forma de compreender e de estar no mundo. Os dois prédios são a marca da aliança.

Construíam, assim, um outro sentido para o moderno. Como queria o Annuario, as almas desorientadas, os operários, os estrangeiros e suas crianças, teriam no Santuário e no Liceu um espaço de tutela que abarcaria suas horas de trabalho, de estudo e seu tempo livre. Como agente de socialização, a religião desenvolve processos de produção e transmissão de um conjunto de 


\section{pro.posições}

$e$-ISSN 1980-6248

http://dx.doi.org/10.1590/1980-6248-2016-0095

dispositivos (físicos, mentais e intelectuais) que contribuem para a construção do mundo social (Setton, 2008). Na conjunção dos interesses da elite, do bispo, da Arquidiocese e dos salesianos, jovens crianças e adultos a serem "educados" eram visados na totalidade de seu tempo de vida.

\section{As Associações: Uma Prática Entre Dois Lugares}

Nas memórias dos salesianos, em livros e nos documentos encontrados, os dois edifícios aparecem interligados. Nos arquivos da Arquidiocese de São Paulo ${ }^{11}$, os documentos para lá enviados pelos religiosos salesianos contêm ora o timbre do Liceu, ora o timbre do Santuário e tratam, indistintamente, dos assuntos de um e de outro, como se os espaços se interpenetrassem. Construídos para rituais e práticas distintas, há, contudo, um elemento que transita ou une as pessoas (padres, alunos e paroquianos) em um e em outro prédio: as associações.

A construção dos edifícios foi iniciada pelo Santuário, como já afirmamos. O lançamento da pedra fundamental aconteceu em 24 de junho de 1881, dia do Sagrado Coração de Jesus (SSCJ, 1884). O próprio bispo, Dom Lino Deodato, foi quem presidiu a cerimônia, atestando a importância do empreendimento. É preciso destacar que uma importante associação do período foi lançada pelos Jesuítas, o Apostolado de Oração, destinada ao culto ao Sagrado Coração de Jesus, que deveria auxiliar na substituição das festas populares dos padroeiros (Miceli, 1988). No estado, desde 1871, o jesuíta padre Bartolomeu Taddei havia fundado o primeiro centro do “Apostolado de Oração” em Itu. Na última década do século XIX, contratou o arquiteto francês Louis Marins Amirat para realizar as obras da construção da capela-santuário do Sagrado Coração de Jesus em Itu (SP). No início do século XX ele seria o Santuário Nacional do Sagrado Coração de Jesus. A construção fazia parte de um conjunto de obras e reformas encampadas pelos jesuítas naquela cidade.

O Santuário do Sagrado Coração de Jesus de Campos Elíseos na cidade de São Paulo, embora dividisse o espaço urbano com outros templos também denominados de santuários ${ }^{12}$,

\footnotetext{
11 Pastas: Doutrinação Religiosa, Associação Religiosa, Doutrinação Católica - (1927-1959).

12 Os outros santuários da cidade em 1913 eram: Coração de Maria (em Santa Cecília), São Gonsalo (Praça João Mendes), Ordem Terceira do Carmo (1581, Praça Rio Branco), Convento da Conceição (1859, Avenida Tiradentes), Mosteiro de São Bento (1650), Seminário e Recolhimento da Luz (Avenida Tiradentes). O Santuário de Nossa Senhora da Penha pertence à diocese de São Miguel Paulista e data de 1796. Fora da cidade de São Paulo
} 


\section{pro.posıções}

$e$-ISSN 1980-6248

não tinha concorrentes no que se refere à devoção. O Liceu Sagrado Coração de Jesus, por sua vez, era um empreendimento que concorria com outras instituições que também ofereciam a aprendizagem de um ofício. Para a educação profissional, havia a Casa de Correção e Trabalho $(1825)^{13}$, o Seminário dos Educandos de Sant'Ana $(1825)^{14}$, o Gabinete Topográfico $(1835)^{15} \mathrm{e}$ a Sociedade Protetora da Infância Desvalida $(1874)^{16}$. Os cursos oferecidos - alfaiataria, marcenaria, encadernação, douração, sapataria, pedreiro, tipógrafo - eram similares em quase todos esses estabelecimentos, dentre os quais apenas um era pago. A clientela do Liceu, entretanto, era outra.

No Liceu Sagrado Coração de Jesus recebiam-se internos e externos, como já mencionado. Dentre os primeiros, estavam filhos de fazendeiros do interior do estado e de outras regiões, interessados em se civilizar para a vida urbana. Já o externato anexo atendia crianças de variada procedência, principalmente filhos de operários e imigrantes (Isaú, 1985). Eram os professores do externato que se dedicavam ao oratório festivo nos finais de semana, atividade que contava, na memória salesiana, com 500 meninos (Azzi, 2002) ${ }^{17}$. Para Azzi (2002, p. 127), os colégios salesianos facilitaram a "transição adequada da vida rural para a vida urbana": aprender a regular seu tempo pelo relógio, responder prontamente à sineta e à campainha e

havia: Basílica de Aparecida (Aparecida, 1888), Bom Jesus (Pirapora, 1850), Bom Jesus (Bom Jesus dos Perdões) (Annuario, 1913).

${ }^{13}$ Funcionava em uma das salas da cadeia pública e, mais tarde, no quartel da Tropa da Primeira Linha. Era destinada àqueles que deveriam cumprir trabalhos forçados. Gradativamente a Casa assumiu características de instituição escolar e, em 1870, possuía instalações para encadernação, oficinas de alfaiate, sapateiro, marceneiro, latoeiro, ferreiro e trançadores de palha para chapéu. Transformou-se no complexo penitenciário do Carandiru (Etchebéhère-Júnior \& Trufem, 2010).

${ }^{14}$ Teve seu início na antiga fazenda dos jesuítas, onde hoje se localiza o bairro de Santana. O Seminário recebia órfãos e pensionistas que pagavam entre $3 \$ 200$ e $6 \$ 400$. Os concluintes eram enviados para o Arsenal das Docas da Corte ou para a Fábrica de Ferro de São João de Ipanema como forma de indenização. Em 1865 transformouse em Instituto de Educandos e Artífices (Etchebéhère-Júnior \& Trufem, 2010).

${ }^{15}$ Foi criado por lei provincial, funcionava no antigo Palácio dos Governadores, na região do Pátio do Colégio, centro da cidade. Formava profissionais para trabalhar na construção de estradas. O concluinte recebia a Carta de Engenheiro de Estradas. Fechou em 1838, reabriu em 1842 e fechou novamente em 1848 (Etchebéhère-Júnior \& Trufem, 2010).

16 Funcionou na chácara do Senador Queirós com os recursos deixados por Dona Ana Rosa de Araújo (Etchebéhère-Júnior \& Trufem, 2010).

17 As atividades iniciais da congregação na Itália foram organizadas em torno do Oratório festivo, que reunia crianças e jovens considerados em perigo moral, em praças aos domingos e dias santos para evangelizar, promover brincadeiras e doutrinar. Aos poucos o oratório de Valdocco tornou-se local de abrigo, moradia e educação profissionalizante para jovens de 12 a 18 anos (Azzi, 2000). Dom Bosco também elaborou o "Sistema Preventivo" que se encontra em seus textos, nas Constituições Salesianas e Regulamentos, e em um pequeno texto intitulado “O Sistema Preventivo na Educação da Juventude”, datado de 1877 (Nicolau, n.d.). 


\section{pro.posições}

$e$-ISSN 1980-6248

http://dx.doi.org/10.1590/1980-6248-2016-0095

viver limitado entre paredes. Aqui parece expressar-se a discordância de tempos: era preciso impor um tempo aos grupos que chegavam à cidade.

Para a Igreja, a modernização dos padrões de comportamento para a vida na cidade deveria ser acompanhada de elementos que estimulassem a coesão social e cuidassem de manter os cidadãos afastados dos perigos do protestantismo, do espiritismo, do liberalismo, do anarquismo e do socialismo. Não só o tempo de estudo e de trabalho deveria ser regulado, mas todo o dia do aluno. Nesse projeto, as associações jogavam um papel central. Essa seria a "página mais brilhante" do Anuário da Arquidiocese, se as associações dedicassem maior atenção à escrituração e ao cuidado com seus arquivos, afirmava o redator (Annuario, 1913).

Como quer que seja, à parte algumas irmandades, das quaes só diremos que... ainda existem na Archidiocese, as associações prosperam quanto ao espiritual, dando às nossas principaes parochias e santuarios esse aspecto de vida religiosa, que tão alto fala e a todos edifica. (p. 24)

A intenção era preencher as paróquias de associações, comandadas por religiosos, em substituição às antigas irmandades, comandadas por leigos. Evidencia-se, no ataque a essas últimas, o ponto de divergência: a gestão do religioso deve estar nas mãos da hierarquia da Igreja.

Falando em associações, entenda-se que não nos referimos a irmandades, cuja organisação muitíssimo pouco ou nada aproveita à vida religiosa das parochias - porque nela o padre não é "cousa alguma".... as associações bem organisadas espelham a parochia .... Mais ainda: a parochia é o que são as suas associações [ênfase no original] (Annuario, 1913, p. 23).

Elas teriam por função agregar as famílias que viviam na atribulação da cidade grande, espécie de "cimento social":

Interesses materiais, exigências da profissão não formam um bloco coeso, nada as une, não possuem as mesmas aspirações.... nas grandes cidades ignora-se o que se passa na visinhança, na mesma rua, no mesmo bairro. Barreira eficaz a essa desagregação anti-social, ergue-se porém o campanário, à cuja sombra nascem ou medram relações de amizade ou de simples conhecimento, cimentando famílias e indivíduos em torno da mesma crença. Tirae esse ideal de força e cohesão, e as grandes cidades serão como montões de aréa, cujos grãos se tocam, se superpõem, crescem, avultam, sem se entenderem, sem se comunicarem entre si, mais que por uma relação artificial e fugitiva [ênfase no original]. (Annuario, 1913, p. 24)

A coesão dos católicos, afirma o redator, só pode ser conseguida pelo espírito de associação. Segue afirmando que a paróquia não pode ser a cidade, mas sim um "redil, onde as ovelhas conhecem o pastor, e este as distingue e as chama cada uma por seu nome. É sabido como, 


\section{pro.posıções}

$e$-ISSN 1980-6248

http://dx.doi.org/10.1590/1980-6248-2016-0095

nas grandes cidades, vivem isoladas as famílias, geralmente pouco relacionadas entre si" [ênfase no original] (Annuario, 1913, p. 24). O foco é transformar o paroquiano em paroquiano prático, ou seja, aquele que pratica os sacramentos, que se envolve com as atividades da paróquia. Havia 204 associações conhecidas em 1913, dentre elas era recomendado, de modo particular, o Apostolado da Oração (Annuario, 1913).

No Liceu, desde sua abertura, havia três associações devotas, como aquelas constituídas por Dom Bosco na Itália: a companhia de São José (destinada aos aprendizes) e as companhias de São Luís e do Santíssimo Sacramento (destinadas aos estudantes) (Azzi, 2002). Os jovens que delas participassem seriam exemplos de bom comportamento e deveriam influir sobre os seus colegas. Em 23 de junho de 1922 também foi fundado o Pequeno Clero, com a finalidade de "dar realce e esplendor às funções religiosas realizadas no Santuário do Coração de Jesus" (Azzi, 2002, p. 43). Os sócios ajudavam na missa e aprendiam a auxiliar em diversas tarefas sacras do Santuário. Sua obrigação principal era o bom comportamento, a civilidade:

Apresentar-se bem trajados, com botinas pretas engraxadas, mãos limpas, unhas aparadas; observar o silêncio, e voltar em seguida imediatamente para a respectiva divisão; ser de bom exemplo aos outros nas orações, nos cantos sagrados e nas visitas ao Santíssimo Sacramento; finalmente, fazer com que muitos alunos aprendessem a ajudar a missa. (Liceu, fev.-mar. 1922, citado por Azzi, 2002, p. 139)

Havia também a Guarda de Honra [do Sagrado Coração] e o Apostolado de Oração. Neles, a ênfase era sobre as responsabilidades pessoais e a reparação dos pecados dos hereges e dos maus cristãos por meio das boas obras. A Guarda de Honra do Liceu foi fundada em 8 de dezembro de 1889. No Arquivo da Cúria Metropolitana de São Paulo há um pedido feito pelo diretor do Liceu, padre Lourenço Giordani, para autorização de seu funcionamento. Entre 1894 e 1909 as inscrições à Guarda chegaram a 2.198, e essa associação chegou a assumir algumas despesas do Santuário e a responsabilizar-se pela coleta (Isaú, 1992). Dom Lino outorgou indulgência de quarenta dias aos irmãos da associação por cada hora de guarda. E completava (Deodato, 1889):

Exhortamos também a todos os Reverendissimos Parochos de nossa Diocese para que se esforcem por tornar patente a seos respectivos rebanhos esta fonte de salvação, lembrando-lhes que "as pessoas que a propagarem terão seos nomes escriptos no Coração de Jesus, e nunca serão dele apagados". 


\section{pro.posıções}

$e$-ISSN 1980-6248

http://dx.doi.org/10.1590/1980-6248-2016-0095

As associações concorriam com os foot-ballers, os cinemas, e, além deles, com outras associações. A segunda metade do século XIX e as primeiras décadas do século seguinte foram períodos de grande crescimento de associações com objetivos diversos, agregando desde integrantes da elite política do País até ex-cativos (Jesus, 2007). O fenômeno associativo, com práticas de solidariedade horizontais, apareceu nesse momento em que o mercado de trabalho estava em disputa por nacionais e estrangeiros. As associações operárias surgiram com a crise da hegemonia política e cultural senhorial. Pela característica das relações horizontais, colocaram-se na contramão das associações católicas que visavam à hierarquia: tinham o foco no leigo, mas a posição de direção, de prescrição e de tomada de decisões centralizava-se nas mãos do padre.

Nas décadas de 1920 e 1930, organizaram-se as Associações dos universitários católicos, a Conferência Nacional de Operários Católicos, a Conferência da Imprensa Católica e as Associações de Professores Católicos. É preciso lembrar a importante atuação da Liga Eleitoral Católica na Constituição de 1934 e da Liga do Professorado Católico de São Paulo, que logrou mobilizar militantes e responsáveis por políticas públicas, que levavam seus habitus católicos para seus discursos e suas práticas sociais (Pinheiro, 2015).

Não se encontraram documentos com os quais seja possível precisar o número de associações que existiram no Santuário e no Liceu ao longo dos anos. Até mesmo o redator do Annuario (1913) lamentava o pouco cuidado com os registros dessas sociedades. Entretanto, a partir dos programas de festividades e das fotos do Arquivo Salesiano de São Paulo, é possível encontrar indícios de que se diversificaram e atingiram número significativo de associados nas primeiras décadas do século XX.

Em um Programa-Convite para a festa do Sagrado Coração, realizada em junho (não foi possível identificar o ano, provavelmente década de 1920), convida-se a população para nove dias de palestras com o padre Carlos Leôncio, que desenvolveria temas sobre a devoção ao Sagrado Coração e os ideais de grandeza, humanidade, felicidade, harmonia, vida e ação, bondade, pureza, justiça, associação e progresso. Note-se, entre os diversos valores trabalhados durante o retiro, a presença do tema da associação. O que teria dito o padre a respeito? Pode-se imaginar que teria sido feita uma distinção entre boas e más associações, considerando que concorriam com outras, de operários, beneficentes ou mutualistas, cuja presença era expressiva na cidade (Luca, 1990)? 


\section{pro.posições}

$e$-ISSN 1980-6248

http://dx.doi.org/10.1590/1980-6248-2016-0095

O programa também indica que participariam da festa o coro do Santuário e as diversas associações que ele abrigava: Guarda de Honra de homens e senhoras, Damas de Nossa Senhora Auxiliadora, Associação de Lourdes, Pia Associação das Filhas de Maria. Informava ainda que

às 15 horas sahirá do Santuario imponente procissão levando a veneranda e antiga imagem do S. Coração de Jesus, a mesma que aqui se venera desde o início do Santuario. Tomarão parte todas as Associações do Santuario, vários collegios, os Congregados Marianos e os devotos do S. Coração de Jesus. (SSCJ, Programa, n.d.[a])

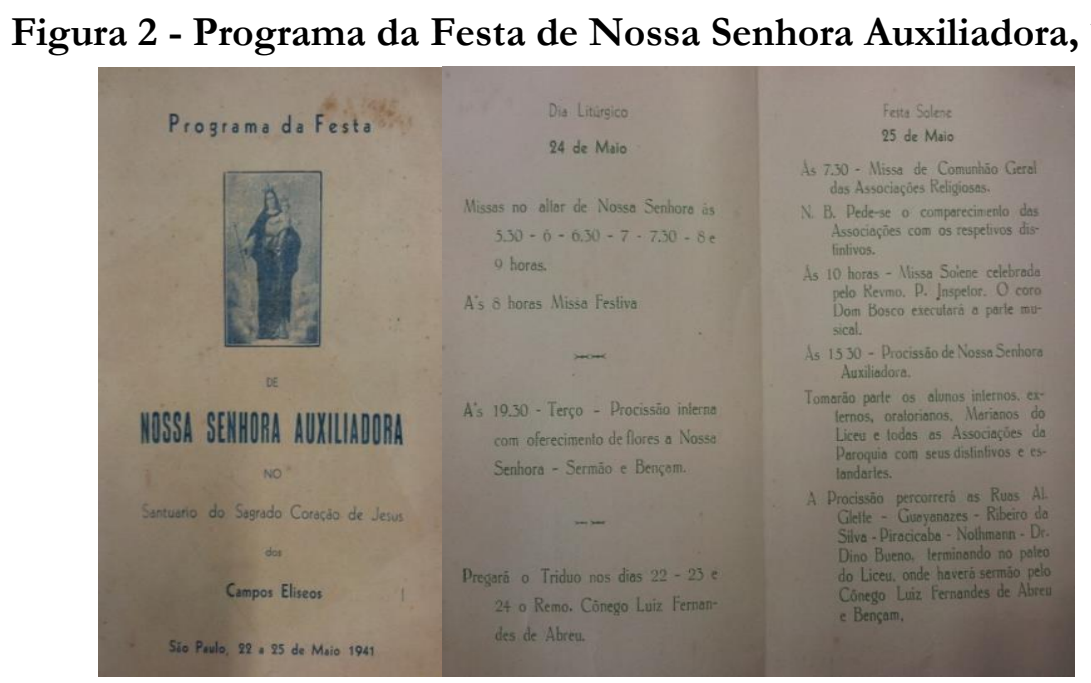

Fonte: Arquivo Salesiano de São Paulo

A análise dos Programas ${ }^{18}$ fornece uma visão geral do espetáculo que se montava em ocasiões festivas. As associações e todos que se juntassem à procissão percorreriam as alamedas Glete, Ribeiro da Silva, Dr. Dino Bueno, Barão de Piracicaba, Nothmann e a rua Guaianazes, contornando todo o bairro. Quando a procissão ocorria ao entardecer, pedia-se que os moradores do bairro iluminassem as fachadas de suas casas. Em ocasiões festivas, eram convocados os alunos internos, externos, oratorianos e todas as associações do Santuário. Os membros dessas sociedades deveriam comparecer com seus distintivos e estandartes. Para a celebração, os bancos da nave central e da esquerda eram reservados aos alunos. As fotos

\footnotetext{
18 Foram encontrados e analisados os seguintes programas: Programa da Semana Santa (1937), Programa-Convite Paschoa dos Ex-alumnos (1938a), Programa Maio, Mês de Maria (1938b), Programa Solenes Festejos da Paróquia do Sagrado Coração de Jesus em Honra do Seu Titular (1953a), Programa Semana de Cristo-Rei (1953b), Programa Retiro Anual da Guarda de Honra do Santuário (1953c), Programa Festa do Divinissimo Coração de Jesus (n.d. [a]), Programa Solene Tríduo Eucarístico Mariano (n.d.[b]).
} 


\section{pro.posıções \\ $e$-ISSN 1980-6248}

presentes no Arquivo Salesiano indicam que as procissões eram concorridas, e o largo se via apinhado de pessoas.

Figura 3 - Pessoas em frente à fachada do Santuário em dia de festa, n.d.

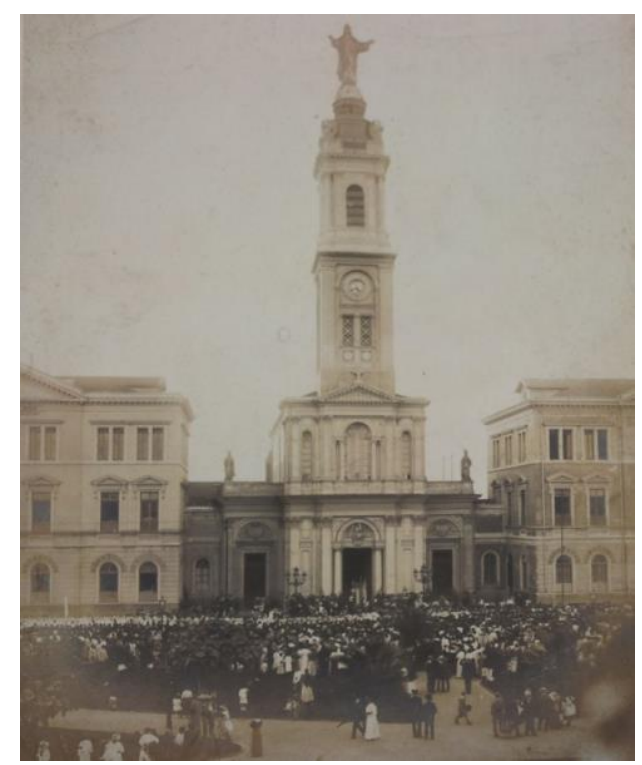

Fonte: Arquivo Salesiano de São Paulo

Além dos retiros, as festas eram a ocasião em que, pelas ruas do bairro, os associados e os fiéis em geral forneciam os exemplos de civilidade e piedade cristã. Nas procissões, as crianças tinham lugar de destaque, as menores à frente, vestidas de anjos. Na Figura 4, as meninas olham para a câmera e, em torno do grupo, algumas senhoras as acompanham, para que nada saia da ordem. 


\section{pro.posições \\ $e$-ISSN 1980-6248}

Figura 4 - Crianças preparadas para a procissão, em frente ao Santuário, n.d.

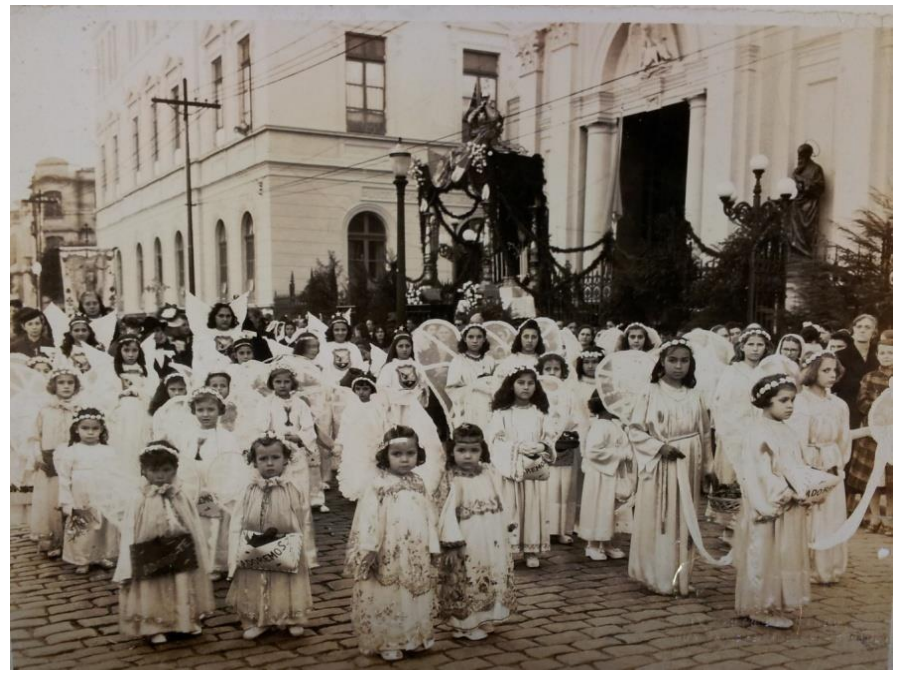

Fonte: Arquivo Salesiano de São Paulo

De uma das associações para crianças do Santuário foi preservada a Ata no Arquivo Salesiano. Trata-se da Cruzada Eucarística, fundada por determinação do arcebispo metropolitano, D. José Gaspar, em 6 de janeiro de 1940 (SSCJ, 1940). Foram admitidas 20 meninas efetivas e 16 aspirantes, escolhidas dentre aquelas que já participavam da Liga Eucarística, outra associação para crianças. Dentre elas, há apenas duas negras.

Figura 5 - Meninas da Cruzada Eucarística, n.d.



Fonte: Arquivo Salesiano de São Paulo 


\section{pro.posıções \\ $e$-ISSN 1980-6248}

http://dx.doi.org/10.1590/1980-6248-2016-0095

A foto que abre a Ata apresenta as meninas posicionadas na escada do Santuário. Atrás, a madrinha da bandeira segura o estandarte que deveria ser exibido em dias festivos, percorrendo as ruas do bairro em procissão. Duas senhoras as acompanham, provavelmente aquelas que assinam a Ata, Maria Esther Grespan e Maria José L. Almada. Todas as participantes assistiram a dez reuniões preparatórias com o diretor, Padre José Luiz Giacatto. A primeira página da Ata apresenta um texto em latim sobre indulgências. Segue texto do pároco do Santuário, Luiz Gonzaga de Almeida, esclarecendo que a Cruzada está inscrita no Apostolado de Oração e, dessa forma, compartilha de todas as graças e indulgências dessa associação. Certamente as meninas participantes eram informadas e tinham todos os esclarecimentos necessários a esse respeito, como estímulo ao cumprimento das ações esperadas.

Figura 6 - Página da Ata declarando a participação da associação nas indulgências

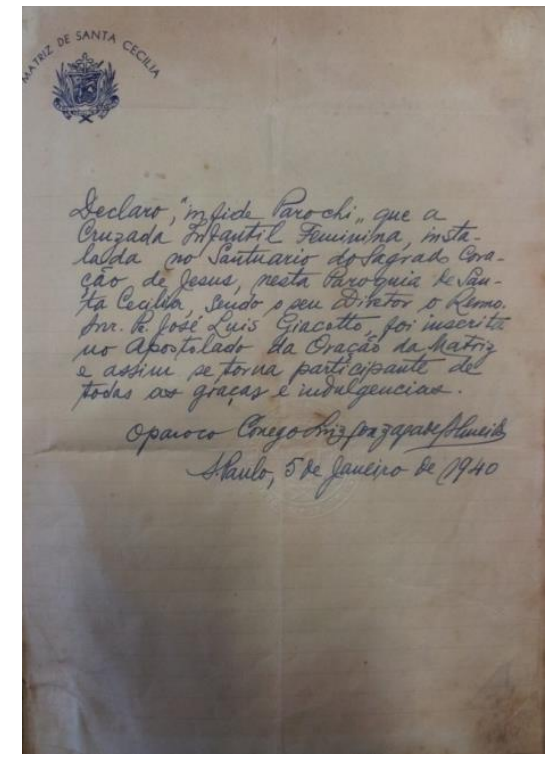

Fonte: Arquivo Salesiano de São Paulo

A cerimônia de fundação desta associação aconteceu às 19 horas no próprio Santuário e foi presidida pelo diretor da Cruzada.

Seguidas pela madrinha da bandeira e pela zeladora da Cruzada as meninas uniformizadas se dirigiram ao altar mor, ocupando os lugares reservados para elas. Em seguida o Revmo Diretor leu a carta de agregação da Cruzada, ao Apostolado da Oração assignada pelo Revmo Vigário da Parochia de Santa Cecilia. Iniciando a cerimonia o Revmo Diretor benzeu as fitas e os distintivos entregando-os as...Cruzadinhas efetivas...(SSCJ, 1940, f. 9, verso) 


\section{pro.posıções}

$e$-ISSN 1980-6248

http://dx.doi.org/10.1590/1980-6248-2016-0095

\section{Figura 7 - Interior do Santuário do Sagrado Coração de Jesus, altar-mor}

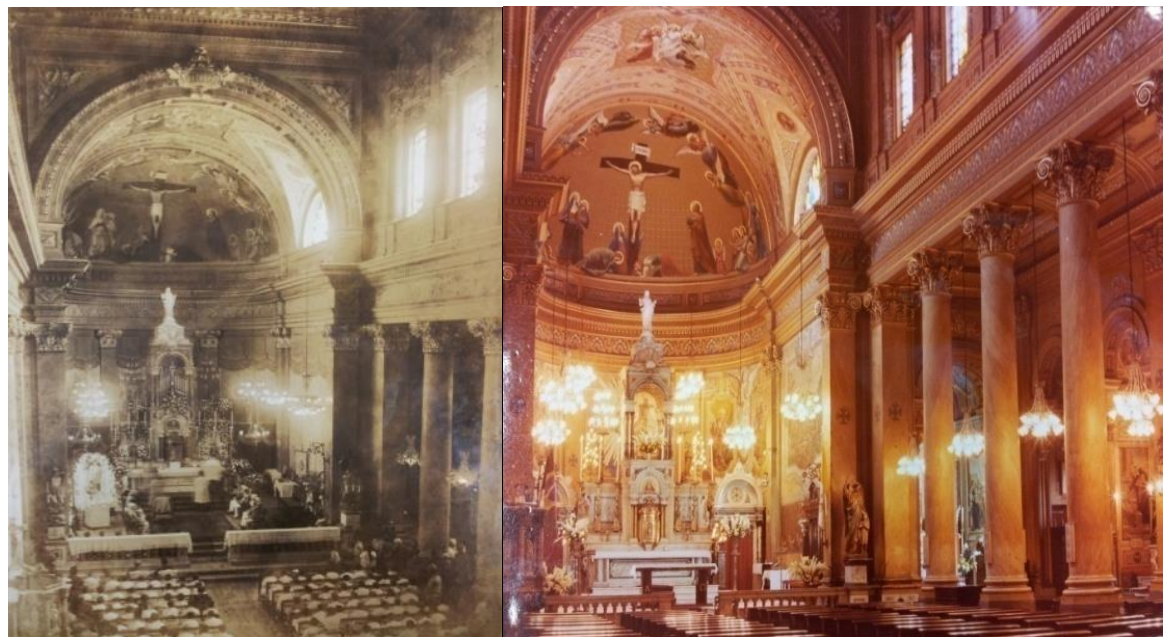

A primeira foto provavelmente data da década de 1910. A segunda é mais recente, sem data.

Fonte: Arquivo Salesiano de São Paulo

Quais as impressões das meninas, ao se dirigirem ao altar-mor? A distinção e a hierarquização eram aprendidas logo no primeiro encontro com o diretor. Algumas delas tinham posição de destaque, como a madrinha da bandeira e a zeladora. Todas, contudo, poderiam pensar que foram escolhidas entre muitas. Padre Giacatto informava os motivos pelos quais algumas não entraram para a associação: elas “tomaram parte no Carnaval” (SSCJ, 1940, f. 10). Prossegue o registro na Ata:

Em seguida, disse que as Cruzadinhas devem tornar-se verdadeiras Apóstolas levando sempre uma vida mui ativa assemelhando-se aos canais que recebem a agua e a distribue, assim também é que deve ser uma Cruzada, receber os ensinamentos e espalhá-los não os guardando só para si. O terceiro ponto referido na reunião foi sobre a Quaresma dizendo que são quatro as maneiras principais para prepara-la: $1^{\circ}$. Oração, indicando a pratica melhor - a Via Sacra; $2^{\circ}$. Ouvindo os Sermões; $3^{\circ}$. Ler livros que falem da Paixão de Jesus ou mesmo outros livros santos e $4^{\circ}$. A mortificação dos sentidos com pequenos sacrifícios. (SSCJ, 1940, f. 10, verso)

Um conjunto de práticas deveria ser observado, ocupando o tempo das meninas quando não estivessem na escola ou nas reuniões da associação. Elas garantiriam que estivessem atentas a espalhar, como canais de água, os ensinamentos que recebiam do diretor e das leituras indicadas. As atas seguintes fornecem uma amostra de como o diretor orientava as meninas e quais práticas deveriam cumprir para alcançar determinado posto no interior da associação. $\mathrm{O}$ objetivo maior era ganhar a "ficha de ouro". Para isso, deveriam ser assíduas às missas, aos 


\section{pro.posıções}

$e$-ISSN 1980-6248

http://dx.doi.org/10.1590/1980-6248-2016-0095

catecismos e às comunhões. Todos os domingos deveriam assistir à missa e dedicar a parte da tarde a atividades piedosas, como orações e leituras. O período de preparação para a Páscoa deveria ser o momento de maior atividade das Cruzadinhas: comungar todos os dias. Imagens impressionantes eram evocadas pelo padre diretor: "Todas as Cruzadinhas devem fazer alguns sacrifícios neste tempo [Quaresma] e depois colocar o número deles em uma caixinha na Igreja, isso agrada a Jesus tirando-lhe os espinhos e colocando os sacrifícios em lugar dos primeiros como pedras preciosas" (SSCJ, 1940, f. 11).

O uso de imagens impressionantes (a retirada dos espinhos do coração de Jesus, ou a metáfora das meninas como canais d'água), que marcam e ativam emoções, é um artifício para controle da memória individual que pode ser observado em outras congregações, indicando que compõe a pedagogia católica (Leonardi, 2013) ${ }^{19}$. A prática de controle da memória está presente nas regras e na constituição de algumas congregações criadas durante o século XIX, prescritas para uso tanto pelos religiosos quanto pelos leigos.

Seguem os preceitos de Tomás de Aquino, que leu a antiga arte da memória, antes tomada como parte da Retórica e técnica para memorização, como parte da Prudência, dando a ela uma finalidade moral (Yates, 2007). Para Aquino, dessas imagens depositadas na memória derivam intenções da faculdade avaliadora, mas, como as intenções escapam facilmente à alma, é preciso o auxílio dos sentidos, especialmente da visão, para que as intenções de boas ações sejam duradouras. Note-se que a técnica ou prática tinha o foco na memória individual.

Lembrando-se de como se comportar, a menina poderia ser exemplo para suas amigas. A tríade da memória, do exemplo e da ação, núcleo estruturante de algumas congregações religiosas do século XIX, pelo qual se recrutavam e produziam determinados tipos de vínculos entre as religiosas (Leonardi, 2010), repete-se na ação com os leigos. Cada uma das meninas "cruzadinha" deveria ter a sua "pecadora" e esforçar-se para levar a Jesus a alma que estava dele afastada (SSCJ, 1940). Além disso, elas deveriam espalhar as boas leituras. As "amiguinhas de Jesus" (SSCJ, 1940, f. 12) escolheriam, na Semana Santa, meia hora por dia para honrar a Jesus no Santíssimo, em grupos de seis. Ao completarem cinco horas e meia, deveriam todas participar da última meia hora em conjunto, uniformizadas, de branco. Além disso, tinham a obrigação de conduzir mais quatro ou cinco meninas para a comunhão pascal, o que agradaria a Jesus. Se na

19 A análise do uso das imagens agentes para controle da memória individual é tributária dos estudos de Yates (2007) e Almeida (1999). 


\section{pro.posições}

$e$-ISSN 1980-6248

http://dx.doi.org/10.1590/1980-6248-2016-0095

Páscoa o objeto das atenções e dos cuidados para "agradar" era Jesus, no mês de maio, tradicionalmente dedicado a Maria, era para ela que as Cruzadinhas deveriam apresentar outras meninas para comungar. No domingo do Divino Espírito Santo, novas Cruzadinhas seriam admitidas e algumas seriam promovidas para o Apostolado de Oração.

Lamentavelmente, não há registros escritos das associações formadas por meninos ou por homens e mulheres adultos. As fotos, contudo, indicam que as associações incluíam alunos e pessoas da paróquia. É possível que as práticas de controle da memória, o foco no exemplo, a frequência a rituais no Santuário e a prescrição de práticas a serem realizadas fora desse espaço fossem reproduzidos para outras associações, adaptando-se à idade e ao sexo dos associados. A Congregação Mariana e as Filhas de Maria, formadas, respectivamente, por homens e por mulheres, reuniam significativa quantidade de pessoas em seus retiros.

Figura 8 - Filhas de Maria reunidas no Colégio de Santa Inês ${ }^{20}$, n.d.

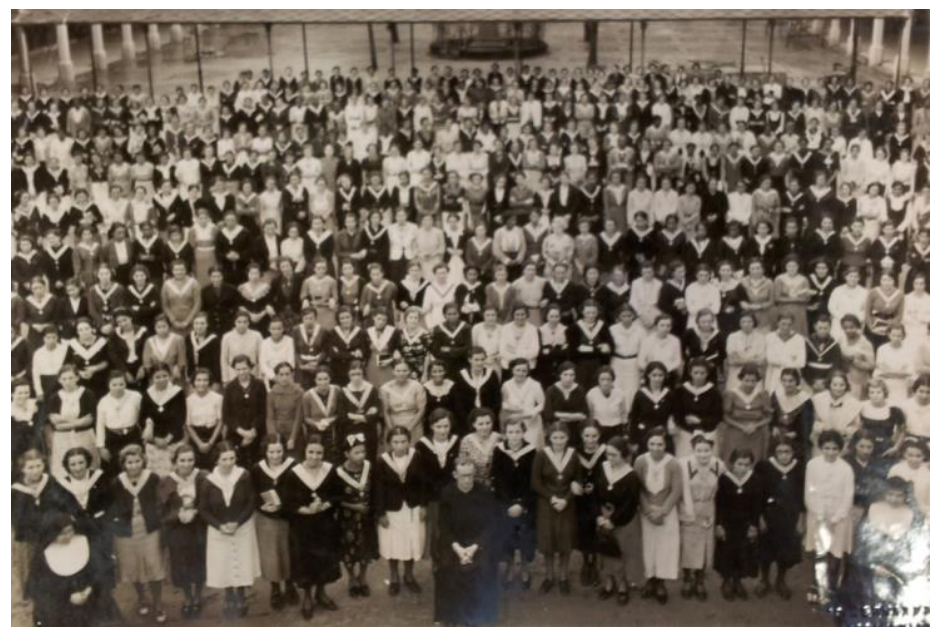

Fonte: Arquivo Salesiano de São Paulo

${ }^{20}$ Administrado pelas irmãs salesianas 


\section{pro.posıções \\ $e$-ISSN 1980-6248}

http://dx.doi.org/10.1590/1980-6248-2016-0095

Figura 9 - Retiro Mariano, 1930

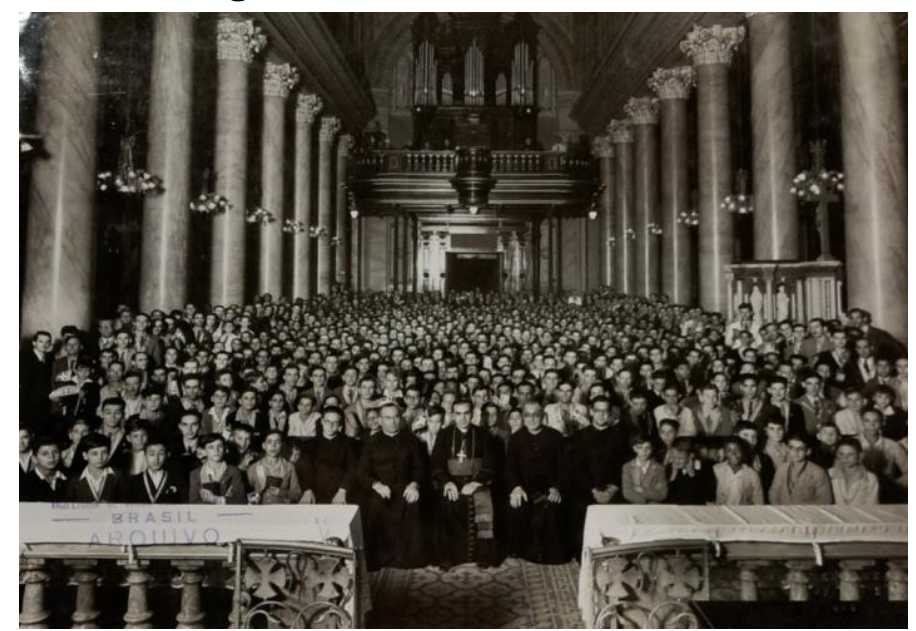

Fonte: Arquivo Salesiano de São Paulo

\section{Considerações finais}

Entre o Liceu e o Santuário do Sagrado Coração de Jesus, as associações desenvolveram ações e práticas que procuravam organizar o tempo dos indivíduos na cidade. Inseria-se, nos dois prédios, uma outra temporalidade, contrária aos usos dos meninos vindos da zona rural, uma outra forma de conceber e utilizar o tempo para os imigrantes e para os aprendizes, a fim de afastá-los dos perigos da cidade, do anarquismo e do socialismo, das superstições e dos divertimentos considerados pouco sadios. Como no velho ditado popular, "mente vazia, oficina do diabo". Vinculados às associações, alunos, ex-alunos, mas não só, homens, mulheres e crianças dos dois sexos tinham obrigações regulares: participar das reuniões, frequentar os sacramentos, ler textos indicados e se ocupar de conduzir para essas práticas outras pessoas. Sempre com um padre coordenando as atividades, as associações visavam, também, substituir as antigas irmandades que eram administradas por leigos, minimizar as interpretações diversas da doutrina, controlar a arrecadação e oferecer o "cimento" social necessário para os habitantes da cidade em crescimento.

Festas, retiros e atividades cotidianas ocupavam parte do tempo dos associados. Tendo socializado seus membros, afastando-os dos divertimentos da cidade, preenchendo seu tempo livre, modelando padrões de comportamento, hábitos mentais e morais, cada associação desfilaria em dias de festa, seguindo as procissões. Memória e imitação compunham suas 


\section{pro.posıções \\ $e$-ISSN 1980-6248}

http://dx.doi.org/10.1590/1980-6248-2016-0095

práticas socializadoras, que faziam irradiar, pela cidade em crescimento - no corpo, no comportamento das pessoas e nas procissões - a cultura católica.

O tempo católico da tradição reforça as hierarquias e as separações, marcando espaços para homens, para mulheres e para diferentes grupos sociais. Na Figura 9 vê-se que os "marianos" são das mais diversas idades. À direita dos padres diretores do retiro, estão os garotos uniformizados, com medalhas e com folhetos à mão. À esquerda, grupo no qual há um único negro, entre os meninos que aparentam ter as roupas mais gastas, alguns levam as mãos ao ouvido no momento da foto, outros cruzam os braços e não seguem o exemplo dos padres ou dos meninos do lado oposto. Mesmo com uma pedagogia estruturada para o controle e para a homogeneidade dos comportamentos, algo escapava. 


\section{pro.posıções}

$e$-ISSN 1980-6248

http://dx.doi.org/10.1590/1980-6248-2016-0095

\section{Referências}

\section{Fontes}

Arquivo da Cúria Metropolitana de São Paulo

Actas y Decretos del Concilio Plenario de la America Latina (1906). Roma: TipografíaVaticana.

Dom Lino Deodato. Correspondência oficial (1876-1880).

Annuario e Estatística Geral da Archidiocese de S. Paulo (1913). São Paulo. 1912 - 1913. São Paulo: Typ. Siqueira, Nagel \& C.

\section{Arquivo dos Salesianos de São Paulo}

Santuário do Sagrado Coração de Jesus. (1884-1885). Livro Tombo para a Capela do Sagrado Coração de Jesus.

Santuário do Sagrado Coração de Jesus. (1937). Programa da Semana Santa.

Santuário do Sagrado Coração de Jesus. (1938a). Programa-Convite Paschoa dos Ex-alumnos.

Santuário do Sagrado Coração de Jesus. (1938b). Programa Maio, Mês de Maria.

Santuário do Sagrado Coração de Jesus. (1940). Ata da Instalação da Cruzada Eucarística Infantil do Santuário do Sagrado Coração de Jesus.

Santuário do Sagrado Coração de Jesus. (1941). Programa da Festa de Nossa Senhora Auxiliadora.

Santuário do Sagrado Coração de Jesus. (1953a). Programa Solenes Festejos da Paróquia do Sagrado Coração de Jesus em Honra do Seu Titular.

Santuário do Sagrado Coração de Jesus. (1953b). Programa Semana de Cristo-Rei.

Santuário do Sagrado Coração de Jesus. (1953c). Programa Retiro Anual da Guarda de Honra do Santuário.

Santuário do Sagrado Coração de Jesus. (n.d. [a]). Programa Festa do Divinissimo Coração de Jesus.

Santuário do Sagrado Coração de Jesus. (n.d. [b]). Programa Solene Tríduo Eucarístico Mariano. 


\section{pro.posıções}

$e$-ISSN 1980-6248

http://dx.doi.org/10.1590/1980-6248-2016-0095

\section{Bibliografia}

Almeida, M. J. de (1999). A educação visual da memória. Imagens agentes do cinema e da televisão. Pro-Posições, 10(2), 5-18.

Alves, G. L. (2005, maio/agosto). Origens da escola moderna no Brasil: a contribuição dos jesuítas. Educação e Sociedade, 26(91), 617-635.

Arroyo, L. (1954). Igrejas de São Paulo. Introdução ao estudo dos templos mais característicos de São Paulo nas suas relações com a crônica da cidade. Rio de Janeiro: José Olympio.

Azzi, R. (1994). O estado leigo e o projeto ultramontano. São Paulo: Paulus.

Azzi, R. (2000). A obra de Dom Bosco no Brasil: cem anos de história. A implementação da obra salesiana (Vol. 1). Barbacena: Centro de Documentação e Pesquisa.

Azzi, R. (2002). A obra de Dom Bosco no Brasil: cem anos de bistória. A implementaşão da obra salesiana (Vol. 2). Barbacena: Centro de Documentação e Pesquisa.

Bittencourt, A. (2015). A era das congregações. In Colóquio Internacional Congregações Religiosas, Educação e Estado Nacional no Brasil, Unicamp, Campinas, 2.

Campos, E. (2007). Os Pais de Barros e a Imperial cidade de São Paulo. Retirado em 02 de março de 2016, de http://www.arquiamigos.org.br/info/info16/i-estudos.htm.

Certeau, M. (1990). L'invention du quotidien. Arts de faire (Vol. 1). Paris: Gallimard.

Charle, C. (2011). Discordance des temps. Une brève histoire de la modernité, le temps des idées. Paris: Armand Colin.

Custódio, M. A. C. (2014). A invenção do cotidiano feminino: formação e trajetória de uma congregação católica (1880-1909). São Paulo: Annablume; FAPESP.

Dallabrida, N. (2001). A fabricação escolar das elites: o Ginásio Catarinense na Primeira República. Florianópolis - SC: Cidade Futura.

Duffy, E. (1998). Santos e pecadores. História dos papas. São Paulo: Cosac \& Naify.

Etchebéhère-Júnior, L., \& Trufem, S. F. B. (2010, setembro/dezembro). O ensino profissionalizante na imperial cidade de São Paulo, Brasil (1823 - 1889). História da Educação - ASPHE/FaE/UFPel, 14(32), 109-141. 


\section{pro.posıções}

$e$-ISSN 1980-6248

http://dx.doi.org/10.1590/1980-6248-2016-0095

Hilsdorf, M. L. S. (2006). História da Educação brasileira: leituras. São Paulo: Thomson Learning.

Isaú, M. (1985). O Liceu Coração de Jesus: cem anos de uma escola em uma cidade dinâmica e em transformação. São Paulo: Editora Salesiana Dom Bosco.

Isaú, M. (1992). O santuário do Sagrado Coração de Jesus (mimeo). São Paulo.

Jesus, R. P. (2007). Associativismo no Brasil do século XIX: repertório crítico dos registros de sociedades no Conselho de Estado (1860-1889). Revista de História, 13(1), 144-170.

Leonardi, P. (2010). Além dos espelhos. Memórias, imagens e trabalhos de duas congregações francesas no Brasil. São Paulo: Paulinas/Fapesp.

Leonardi, P. (2013, janeiro/junho). Construção da memória em congregações católicas: práticas e imagens agentes. Cadernos de História da Educação, 12(1), 295-312.

Luca, T. R. de. (1990). O sonho do futuro assegurado. O mutualismo em São Paulo. São Paulo: Contexto.

Menezes, R. de C. (2009). O sagrado, o convento e "a cidade”. In C. Mafra, \& R. de Almeida, Religiões e cidades. Rio de Janeiro e São Paulo. São Paulo: Terceiro Nome.

Miceli, S. (1988). A elite eclesiástica brasileira. Rio de Janeiro: Bertrand Brasil.

Montero, P. (2011). Selvagens, civilizados, autênticos. A produção das diferenças na etnografia salesiana. São Paulo: Edusp.

Neris, W. S., \& Seidl, E. (2015, maio/agosto). Circulação internacional, politização e redefinições do papel religioso. Revista Brasileira de História da Educação, 15(2), (38), 279308.

Nicolau, F. Moços para a pátria e para a Igreja: a producão de sujeitos nos enunciados da pedagogia salesiana. Retirado em 24 de março de 2016, de http://www.sbhe.org.br/novo/congressos/cbhe4/individuaiscoautorais/eixo03/Fabiana\%20Nicolau\%20-\%20Texto.pdf.

Pinheiro, A. R. (2015, maio/agosto). Instrução do povo sob a proteção do catolicismo militância docente e a expansão da escolarização em São Paulo. Revista Brasileira de História da Educação, 15(2), (38), 193-219.

Rosendahl, Z. (1996). Espaço e religião: uma abordagem geográfica. Rio de Janeiro: UERJ/NEPEC. 


\section{pro.posıções \\ $e$-ISSN 1980-6248}

http://dx.doi.org/10.1590/1980-6248-2016-0095

Setton, M. da G. J. (2008, dezembro). As religiões como agentes da socialização. Cadernos CERU, série 2, 19(2), 15-25.

Silva, A. L. (2011). Mapa de viagem de uma coleção etnográfica - a aldeia bororo nos museus salesianos e o musen salesiano na aldeia bororo. Tese de Doutorado. Departamento de Antropologia, Faculdade de Filosofia, Ciências e Letras. Universidade de São Paulo, São Paulo.

Yates, F. A. (2007). A arte da memória. Campinas: Editora da Unicamp.

Submetido à avaliação em 2 de julho de 2016; revisado em 31 de outubro de 2016; aceito para publicaşão em 21 de dezembro de 2016. 